\title{
Pemetaan Ayat-Ayat al-Qur'an tentang Rumpun Ilmu Agama dalam Perspektif Paradigma Integrasi-Interkoneksi
}

\section{Toto Suharto}

Institut Agama Islam Negeri Surakarta, Indonesia

Email: tosuh71@gmail.com

\begin{abstract}
Abstrak
Kehadiran UU No. 12/2012 tentang Pendidikan Tinggi menjadi angin segar bagi PTKI, karena penyelenggaraan pendidikannya mendapat pengakuan secara konstitusional. Namun demikian, basis konstitusional ini masih menyisakan banyak persoalan, salah satunya dilihat dari perspektif epistemologi integrasi-interkoneksi yang telah menjadikan al-Qur'an dan Hadis sebagai core values bagi keilmuan Islam. Tulisan ini dengan analisis isi menemukan bahwa epistemologi keilmuan integrasi-interkoneksi merupakan gagasan Prof. M. Amin Abdullah yang berusaha memadukan dan mengaitkan antara "ilmu" dan "agama", yang tergambar dalam model Jaring Laba-Laba. Tujuh wilayah rumpun ilmu agama Islam, sebagaimana tertera dalam UU No. 12/2012 mendapat legitimasi al-Qur'an melalui sebaran berbagai ayatnya dalam bentuk pemetaan. Ketujuh bidang rumpun ilmu agama Islam ini posisinya masih berada dalam Lingkar Lapis Dua dalam epistemologi integrasi-interkoneksi model Jaring Laba-Laba. Dengan demikian,tujuh bidang rumpun ilmu agama Islam dalam UU No. 12/2012 ini tidak cukup relevan dengan semangat perubahan dari IAIN ke UIN yang menghendaki adanya peningkatan lapisan dari Lapis Dua ke Lapis Tiga dalam model Jaring Laba-Laba.
\end{abstract}

Kata Kunci: Pemetaan Ayat-ayat al-Qur'an, Rumpun Ilmu Agama, Pendidikan Tinggi Islam, Integrasi-Interkoneksi.

Al-Qur'an adalah kitab induk, rujukan utama bagi segala rujukan, sumber dari segala sumber, basis bagi segala sains dan ilmu pengetahuan. Sejauh mana keabsahan ilmu harus diukur, maka pernyataan al-Qur'an bisa menjadi standarnya. Menurut Mulyadhi Kartanegara, al-Qur'an adalah buku induk ilmu pengetahuan, di mana tidak ada satu perkara apapun yang terlewatkan. Semuanya telah tercover di dalam al-Qur'an, baik yang mengatur hubungan manusia dengan Allah ( $h$ \}abl min Alla $>h$ ), hubungan manusia dengan sesama manusia ( $h$ labl min $a n-N a>s$ ), ataupun hubungan manusia dengan alam dan lingkungan (Kartanegara, 2006, hal. 119). Firman Allah dalam Q.S. al-An'am: 38 jelas menyebutkan bahwa Allah tidak mengalpakan sesuatu apapun dalam al-Qur'an, termasuk terkait dengan ilmu 
pengetahuan. Dengan ayat ini, al-Qur'an dapat menjadi sumber inspirasi bagi lahirnya beragam ilmu pengetahuan, baik ilmu-ilmu sosial, ilmu-ilmu budaya dan humaniora, ilmu-ilmu alam, terutama ilmu-ilmu agama.

Lebih lanjut, Achmad Baiquni (1997, hal. 17) menegaskan bahwa "Sebenarnya segala ilmu yang diperlukan manusia itu tersedia di dalam al-Qur'an". Ayat rujukan yang berkaitan dengan ilmu pengetahuan tidak dimiliki oleh agama ataupun kebudayaan lain. Hal ini mengindikasikan betapa penting ilmu pengetahuan bagi kehidupan manusia. Sekaligus juga membuktikan betapa tingginya kedudukan sains dan ilmu pengetauan dalam al-Qur'an. Dalam konteks ini, al-Qur'an telah memerintahkan kepada manusia untuk selalu mendayagunakan potensi akal, pengamatan, pendengaran dengan semaksimal mungkin (Hasan, 2005, hal. 288), sehingga melahirkan beragam ilmu pengetahuan yang berguna bagi kehidupan manusia itu sendiri.

Universalitas ajaran Islam ditunjukkan oleh al-Qur'an dengan sangat jelas. Al-Qur'an berisi konsep tentang tuhan, penciptaan, manusia dari berbagai aspeknya, alam dan jagad raya, dan keselamatan. Siapa sebenarnya Tuhan itu dijelaskan oleh al-Qur'an. Demikian pula penciptaan, yaitu penciptaan jagad raya ini dan juga penciptaan manusia. Selanjutnya, berbagai makhluk, seperti manusia, malaikat dan jin dijelaskan oleh kitab suci. Al-Qur'an juga menjelaskan tentang alam, seperti bumi, matahari, bulan, langit, laut, api, udara, tumbuh-tumbuhan, hewan dan lain-lain. Selain itu, al-Qur'an juga berbicara tentang keselamatan manusia dan alam. Keselamatan itu dalam perspektif yang sempurna, yaitu baik di dunia dan akhirat. Islam sesungguhnya bukan sebatas memberi petunjuk tentang bagaimana menjalankan ritual, melainkan juga berbicara soal ilmu pengetahuan, manusia unggul, keadilan dan juga petunjuk agar bekerja secara profesional. Dengan demikian, Islam itu bukan sebatas agama, tetapi juga peradaban.

Namun, pada saat al-Qur'an sebagai sumber ajaran Islam memiliki nilai universalitas yang kosmopolitan, tapi pada kenyataannya, kajian Islam di perguruan tinggi Islam masih memiliki keterbatasan. Keterbatasan kajian Islam di semua perguruan tinggi Islam di Indonesia terletak pada keterbatasan wilayah kajian, yang paling banyak adalah hanya memiliki lima fakultas, yaitu ilmu ushuluddin, syari'ah, tarbiyah, dakwah, dan adab. Demikian pula, pelajaran agama Islam mulai dari tingkat dasar, baik di madrasah, di pesantren dan juga di sekolah umum, hanya diformat menjadi pelajaran tauhid, fiqh, akhlak dan tasawwuf, tarikh, dan bahasa arab. Pelajaran selain itu bukan digolongkan sebagai bagian dari pelajaran agama Islam. Dalam konteks ini, Islam hanya dipahami sebagai agama, bukan peradaban, 
sehingga tak jarang terjadi pemahaman keilmuan yang dikotomik, antara ilmu umum dan ilmu agama. Akan tetapi, manakala Islam dipahami sebagai agama dan sekaligus peradaban, maka kajian Islam harus diperluas, dan kelembagaannya pun diubah menjadi bentuk universitas. Kebijakan ini dimaksudkan agar institusi pendidikan tinggi Islam tidak justru memberikan gambaran bahwa Islam itu hanya terbatas. Islam tidak hanya menyangkut persoalan kelahiran, pernikahan, berbagai macam ritual, dan kematian (Suprayogo, 2013). Perubahan pemahaman kajian Islam inilah yang pada gilirannya melahirkan dan mengubah STAIN/IAIN menjadi UIN di Indonesia.

Lahirnya Undang-Undang No. 12 Tahun 2012 tentang Pendidikan Tinggi ini kiranya telah menjadi "angin segar" bagi dunia PTKI di Indonesia, karena dengan UU ini, status PTKI di Indonesia menjadi jelas keberadaannya, yaitu memiliki basis konstitusional, yang setara dengan perguruan-perguruan tinggi umum. Pasal 10 UU ini dengan tegas menyebutkan bahwa agama merupakan salah satu rumpun ilmu pengetahuan bagi perguruan tinggi di Indonesia. Sejumlah PTKIN, baik STAIN, IAIN ataupun UIN, serta 600-ratusan PTKIS, dengan sendirinya dapat menyelenggarakan pendidikan tinggi dengan menjadikan rumpun ilmu agama sebagai bahan kajiannya. Tidak dapat dibayangkan apabila Pasal 10 UU ini tidak mencantumkan ilmu agama sebagai salah satu rumpun ilmu pengetahuan dan teknologi. Tentunya seluruh PTKI baik negeri maupun swasta dapat dibubarkan, karena tidak memiliki basis legalitas-konstitusional dalam penyelenggaraannya (Suharto, 2014, hal. 3).

Di dalam penjelasan pasal 10 UU Pendidikan Tinggi disebutkan bahwa:

"Rumpun ilmu agama merupakan rumpun ilmu pengetahuan yang mengkaji keyakinan tentang ketuhanan atau ketauhidan serta teks-teks suci agama, antara lain ilmu ushuluddin, ilmu syariah, ilmu adab, ilmu dakwah, ilmu tarbiyah, filsafat dan pemikiran Islam, ekonomi Islam, ilmu pendidikan agama Hindu, ilmu penerangan agama Hindu, filsafat agama Hindu, ilmu pendidikan agama Budha, ilmu penerangan agama Budha, filsafat agama Budha, ilmu pendidikan agama Kristen, ilmu pendidikan agama Katholik, teologi, misiologi, konseling pastoral, dan ilmu pendidikan agama Khong $\mathrm{Hu} \mathrm{Cu}$ ".

Dari penjelasan UU Pendidikan Tinggi di atas dapat diketahui bahwa wilayah kajian Islam di PTAI tidak lebih dari sekadar mengkaji keyakinan tentang ketuhanan atau ketauhidan serta teks-teks suci agama, antara lain ilmu ushuluddin, ilmu syariah, ilmu adab, ilmu dakwah, ilmu tarbiyah, filsafat dan pemikiran Islam, 
ekonomi Islam. Jadi, berdasarkan UU PT, ada tujuh wilayah kajian atau fakultas yang menjadi garapan PTKI di Indonesia, yaitu: (1) fakultas ushuluddin, (2) fakultas syariah, (3) fakultas adab, (4) fakultas dakwah, (5) fakultas tarbiyah, (6) fakultas filsafat dan pemikiran Islam, dan (7) fakultas ekonomi Islam.

Namun demikian, basis legalitas-konstitusional itu kiranya masih menyisakan banyak persoalan, yang salah satunya dapat dilihat dari perspektif epistemologi integrasi-interkoneksi. Sebagaimana diketahui, berdirinya UIN sejak 2002 (UIN Jakarta) tidak lain karena mengusung paradigma keilmuan integrasiinterkoneksi. Di dalam paradigma ini, sebagaimana terlihat dalam sejarah keilmuan Islam Klasik, ilmu agama (Islam) dipandang sebagai basis dan ruh bagi seluruh keilmuan Islam yang ada. Epistemologi keilmuan yang dikembangkan oleh UIN Sunan Kalijaga Yogyakarta, misalnya yang mengembangkan paradigma integrasiinterkoneksi, yang oleh M. Amin Abdullah (2006, hal. 101-111) disebut dengan "Jaring Laba-Laba Keilmuan Teo-antroposentris-Integralistik", jelas sekali menjadikan al-Qur'an dan Sunnah sebagai core values segala keilmuan yang dikembangkannya.

Pada konteks itu, kiranya telah terjadi realitas kebijakan yang paradoks. Satu sisi, rumpun ilmu agama yang dalam pasal 10 UU PT setara dan sebanding dengan rumpun ilmu humaniora, rumpun ilmu sosial, rumpun ilmu alam, rumpun ilmu formal, dan rumpun ilmu terapan, merupakan "angin segar" bagi penyelenggaraan pendidikan oleh PTKI, yaitu sebagai basis konstitusionalnya, tapi pada sisi yang lain hal ini menjadi problem epsitemologis ketika vis-a-vis dengan epistemologi integrasi-interkoneksi. Dari problem epistemologis inilah kiranya perlu dilakukan kajian serius dan mendalam mengenai keberadaan rumpun ilmu agama dalam UU PT dengan melihatnya dari perspektif epistemologi integrasiinterkoneksi.

Kajian ini diharapkan memiliki dua kontribusi; praktis dan akademis. Secara praktis, kajian ini dapat menjadi masukan bagi Pemerintah dan DPR terkait produk UU yang disusunnya sebagai sebuah kebijakan, apakah UU No. 12/2012 yang telah disahkan itu bernilai implementatif, dapat diterapkan dalam konteks PTKI di Indonesia. Sedangkan secara akademis penelitian ini merupakan aktivitas ilmiah dalam rangka mengembangkan paradigma keilmuan Islam yang berbasis integrasi-interkoneksi, yang menjadi basis bagi penyelenggaraan PTKI di Indonesia dewasa ini. 


\section{Paradigma Integrasi-Interkoneksi Model Amin Abdullah}

Dengan visi "Unggul dan terkemuka dalam pemaduan dan pengembangan studi keislaman dan keilmuan bagi peradaban" (Kalijaga, 2013), UIN Sunan Kalijaga memiliki core values, yang salah satunya adalah epistemologi keilmuan "integrasi-interkoneksi", yaitu adanya sistem keterpaduan dalam pengembangan akademik, manajemen, kemahasiswaan, kerjasama, dan entrepreneurship (Kalijaga, 2013). Paradigma ini merupakan gagasan Prof. M. Amin Abdullah ketika menjadi Rektor UIN Sunan Kalijaga. Menurut Amin Abdullah, jika selama ini terdapat sekat-sekat yang sangat tajam antara "ilmu" dan "agama" di mana keduanya seolah menjadi entitas yang berdiri sendiri dan tidak bisa dipertemukan, mempunyai wilayah sendiri baik dari segi objek-formal-material, metode penelitian, kriteria kebenaran, peran yang dimainkan oleh ilmuwan hingga institusi penyelenggaranya, maka tawaran paradigma integratif-interkoneksi berupaya mengurangi ketegangan-ketegangan tersebut tanpa meleburkan satu sama lain tetapi berusaha mendekatkan dan mengaitkannya sehingga menjadi "bertegus sapa" satu sama lain (Abdullah, 2006, hal. 92-93).

Adanya dikotomi itu telah berimplikasi pada model pendidikan di Indonesia yang memisahkan antara kedua jenis keilmuan ini. Ilmu-ilmu sekuler dikembangkan di perguruan tinggi umum sementara ilmu-ilmu agama dikembangkan di perguruan tingga agama. Perkembangan ilmu-ilmu sekuler yang dikembangkan oleh perguruan tinggi umum berjalan seolah tercerabut dari nilainilai akar moral dan etik kehidupan manusia, sementara itu perkembangan ilmu agama yang dikembangkan oleh perguruan tinggi agama hanya menekankan pada teks-teks Islam normatif, sehingga dirasa kurang menjawab tantangan zaman. Jarak yang cukup jauh ini kemudian menjadikan kedua bidang keilmuan ini mengalami proses pertumbuhan yang tidak sehat serta membawa dampak negatif bagi pertumbuhan dan perkembangan kehidupan sosial, budaya, ekonomi, politik dan keagamaan di Indonesia (Abdullah, 2006, hal. 92-94).

Paradigma integratif-interkonektif yang ditawarkan Amin Abdullah ini merupakan jawaban dari berbagai persoalan di atas. Integrasi dan interkoneksi antar berbagai disiplin ilmu, baik dari keilmuan sekuler maupun keilmuan agama, akan menjadikan keduanya saling terkait satu sama lain, "bertegur sapa", saling mengisi kekurangan dan kelebihan satu sama lain. Dengan demikian, ilmu agama (baca ilmu keislaman) tidak lagi hanya berkutat pada teks-teks klasik, tetapi juga menyentuh pada ilmu-ilmu sosial kontemporer. 
Dalam paradigma itu, tiga wilayah pokok dalam ilmu pengetahuan, yakni natural sciences, social sciences dan humanities (Abdullah, 2006, hal. 370) tidak lagi berdiri sendiri, tetapi akan saling terkait satu dengan lainnya. Ketiganya juga akan menjadi semakin cair meski tidak akan menyatukan ketiganya, tetapi paling tidak akan ada lagi superioritas dan inferioritas dalam keilmuan. Tidak ada lagi klaim kebenaran ilmu pengetahuan, sehingga dengan paradigma ini para ilmuwan yang menekuni keilmuan ini juga akan mempunya sikap dan cara berfikir yang berbeda dari sebelumnya.

H\{ad\}a>rah al-'Ilm (budaya ilmu), yaitu ilmu-ilmu empiris yang menghasilkan, seperti sains, teknologi dan ilmu-ilmu yang terkait dengan realitas, tidak lagi berdiri sendiri, tetapi juga bersentuhan dengan $\mathrm{H}\{\mathrm{ad}\} a>$ rah al-Falsafah, sehingga tetap memperhatikan etika emansipatoris. Begitu juga sebaliknya, $H\{a d\} a>$ rah al-Falsafah (budaya filsafat) akan terasa kering dan gersang jika tidak terkait dengan isu-isu keagamaan yang termuat dalam budaya teks ( $H\{a d\} a>r a h$ alNas $\{s\})$, lebih-lebih jika menjauh dari problem-problem yang ditimbulkan dan

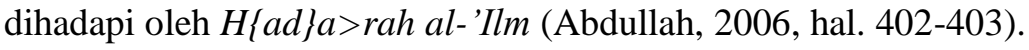

Berikut dikemukakan skema epistemologi integrasi-interkoneksi di antara ketiga wilayah keilmuan Islam (Abdullah, 2006, hal. 405):

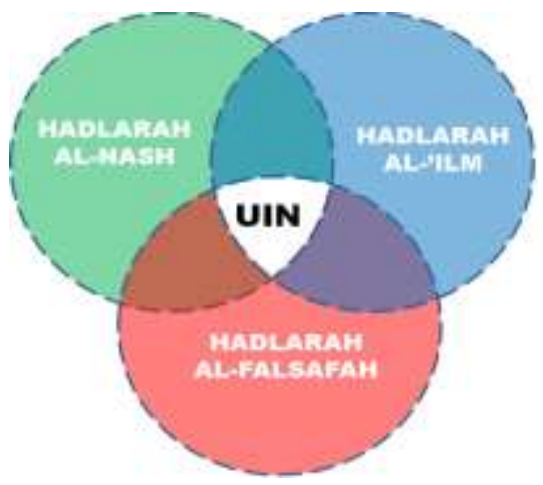

Dengan model integrasi di atas, maka ada tiga wilayah keilmuan, yaitu H\{ad\}a>rah al-Nas\{s\}, H\{ad\}a>rah al-'Ilm dan H\{ad\}a>rah al-Falsafah. Ketiganya harus terintegrasi-terkoneksi. H\{ad\}a>rah al-Nas $\{s\}$ melahirkan ilmuilmu normatif yang tekstual (fiqh, kalam, tasawuf, tafsir, hadis, falsafah, dan lughah). $H\{a d\} a>$ rah al-'Ilm melahirkan ilmu-ilmu empiris (sains dan teknologi). $H\{a d\} a>$ rah al-Falsafah melahirkan ilmu-ilmu rasional (filsafat dan budaya). Tiga dimensi pengembangan wilayah keilmuan di atas bertujuan untuk mempertemukan 
kembali ilmu-ilmu modern dengan ilmu-ilmu keislmanan secara integratifinterkonektif. Paradigma integratif-interkonektif dalam ilmu keislaman tampak dalam "Jaring Laba-Laba Keilmuan" sebagai berikut:

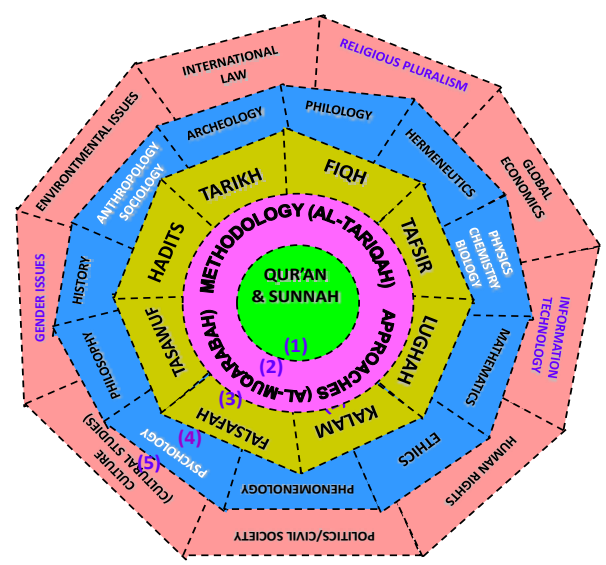

Jaring Laba-Laba di atas menunjukkan bahwa aktivitas keilmuan di Perguruan Tinggi Agama, khususnya IAIN dan STAIN di seluruh tanah air hanya terfokus dan terbatas pada jalur Lingkar Lapis Satu dan jalur Lingkar Lapis Dua, yang terdiri atas Kalam, Falsafah, Tasawuf, Hadits, Tarikh, Fiqh, Tafsir, dan Lughah. Itupun boleh disebut hanya terbatas pada ruang gerak humaniora klasik. IAIN pada umumnya belum mampu memasuki diskusi ilmu-ilmu sosial dan humanities kontemporer seperti tergambar pada jalur Lingkar Tiga (Antropologi, Sosiologi, Psikologi, Filsafat dengan berbagai pendekatan yang ditawarkannya). Akibatnya, terjadi jurang wawasan keislaman yang tidak terjembatani antara ilmuilmu keislaman klasik dan ilmu-ilmu keislaman baru yang telah memanfaatkan analisis ilmu-ilmu sosial dan humaniora kontemporer (Abdullah, 2006, hal. 107108).

Sementara itu, isu-isu sosial, politik, ekonomi, keagamaan, militer, gender, lingkungan hidup, ilmu-ilmu sosial, humanities kontemporer pasca modern, seperti yang tergambar pada jalur Lingkar Lapis Tiga hampir-hampir tidak tersentuh oleh kajian keislaman di tanah air, khususnya di IAIN dan STAIN. Ungkapan seperti "to be religious today is to be interreligious" terasa masih sangat absurd dan unthinkable, bahkan mustahil untuk dipikirkan bagi tradisi keilmuan Lingkar Lapis Dua, meskipun era globalisasi-informasi memaksa manusia beragama era sekarang untuk berpikir demikian (Abdullah, 2006, hal. 109). 
Mencermati paradigma integrasi-interkoneksi Jaring Laba-Laba "Amin Abdullah" dapat dikatakan bahwa paradigma ini terinspirasi oleh kitab suci alQur'an. Al-Qur'an adalah contoh konkrit dari paradigma keilmuan integrasiinterkoneksi, dalam artian yang sesungguhnya. Di dalam al-Qur'an, semua sumber pengetahuan begitu terintegrasi dan terinterkoneksi dengan sangat baik. Setiap informasi ayat yang disampaikan di dalamnya terkandung nilai filosofis, etis, strategis, historis juga metodologis yang saling terintegrasi. Adanya munasabah surat dengan surat, ayat dengan surat, ayat dengan ayat dan bahkan akhir surat dengan awal surat, membuktikan bahwa al-Qur' an secara keseluruhan adalah satu kesatuan bangunan "keilmuan" yang di dalamnya sudah terintegrasi berbagai nilai, pendekatan juga strateginya. Di sinilah letak pentingnya memahami ayat-ayat alQur'an tidak boleh sepotong, tapi harus utuh dan terpadu.

Penyusunan al-Qur'an telah menggunakan dasar-dasar pengetahuan atau metode keilmuan. Hal ini merupakan penjelasan secara tidak langsung bahwa susunan surat-surat maupun ayat-ayat di dalam surat, sudah menggunakan sistematika keilmuan. Artinya, al-Qur'an bukan sekedar merupakan kumpulan surat-surat dan ayat-ayat, yang kemudian dikumpulkan menjadi satu. Tetapi lebih daripada itu, semua komponen-komponen tersebut, satu sama lainnya saling berinteraksi atau berhubungan sehingga menjadi satu kesatuan informasi yang utuh.

\section{Pemetaan Ayat-Ayat al-Qur'an tentang Rumpun Ilmu Agama}

Pemetaan ini dibuat berdasarkan kerangka rumpun ilmu agama bagi PTKI sebagaimana disebutkan dalam UUPT. Ketika UU ini menyebut tujuh ranah keilmuan, maka di sini dipaparkan enam ranah keilmuan, karena ilmu ushuluddin dan pemikiran Islam dijadikan dalam satu ranah keilmuan berbentuk fakultas.

\begin{tabular}{|c|c|c|c|}
\hline No & Keilmuan & Sub-Ranah & Tema \\
\hline 1 & $\begin{array}{l}\text { Ilmu Ushuluddin } \\
\text { dan Pemikiran } \\
\text { Islam }\end{array}$ & Filsafat Agama & $\begin{array}{l}\text { 1) Fitrah beragama manusia, terdapat } \\
\text { di dalam Q.S. 30: 30: } \\
\text { 2) Manusia sebagai khalifah, terdapat } \\
\text { di dalam Q.S. 2: 30; 27: 62; 35: 39; } \\
\text { dan 38: 26. } \\
\text { 3) Manusia makhluk berpikir dan } \\
\text { berakal, di antaranya terdapat di } \\
\text { dalam Q.S. 2: 164; 16: 11-12; 3: } \\
\text { 190-191; 88: 17-20, dan 2: } 164 .\end{array}$ \\
\hline & & $\begin{array}{l}\text { Perbandingan } \\
\text { Agama }\end{array}$ & $\begin{array}{l}\text { 1) Kebenaran agama Islam, terdapat } \\
\text { dalam Q.S. 3: } 19 \text { dan } 85 \text {. }\end{array}$ \\
\hline
\end{tabular}

Intizar, Volume 24, Nomor 1, 2018 
p-ISSN: 1412-1697; e-ISSN: 2477-3816

http://jurnal.radenfatah.ac.id/index.php/intizar

\begin{tabular}{|c|c|c|c|c|}
\hline & & & 2) & $\begin{array}{l}\text { Kebebasan beragama, di antaranya } \\
\text { terdapat dalam Q.S. 18: } 29 \text { dan 109: } \\
\text { 1-3. } \\
\text { Kesamaan agama para nabi, di } \\
\text { antaranya terdapat dalam Q.S. } 23 \text {; } \\
\text { 52 dan 3: } 64 . \\
\text { Ilmuwan yang memikirkan } \\
\text { agamanya, terdapat di dalam Q.S. } \\
\text { 39: } 9 \text {. }\end{array}$ \\
\hline & & $\begin{array}{l}\text { Ilmu al-Qur'an } \\
\text { dan Tafsir }\end{array}$ & 1) & $\begin{array}{l}\text { Al-Qur'an sebagai wahyu Allah, } \\
\text { diturunkan melalui Jibril, kepada } \\
\text { Nabi Muhammad, di antaranya } \\
\text { terdapat di dalam Q.S. 10: 37; 16: } \\
\text { 102; 26: 193; 69: 40; 81: 19; 36: 69; } \\
\text { 69: } 41 \text { dan 6: } 19 . \\
\text { Fungsi dan kedudukan al-Qur'an } \\
\text { sebagai al-z } \text { jikr, al-kita }>b \text { dan } a l- \\
\text { furqa >n, di antaranya terdapat di } \\
\text { dalam Q.S. 15: 19; 15: 1; dan 25: } 1 . \\
\text { Al-Qur'an diturunkan pada bulan } \\
\text { Ramadan secara berangsur-angsur, } \\
\text { terdapat di dalam Q.S. } 2: 185 ; 17: \\
\text { 106 dan 76: } 23 \text {. }\end{array}$ \\
\hline \multirow[t]{2}{*}{2} & Ilmu Syariah & $\begin{array}{l}\text { Al-Ahwal al- } \\
\text { Syakhshiyyah }\end{array}$ & 5) & $\begin{array}{l}\text { Perintah nikah, terdapat di dalam } \\
\text { Q.S. 4: } 3 . \\
\text { Hukum perceraian, terdapat } \\
\text { di dalam Q.S. 2: } 227 \text { dan 4: } \\
\text { 19. } \\
\text { Hak dan kewajiban suami isteri, } \\
\text { terdapat di dalam Q.S. 2: 233; 4: 34; } \\
\text { 65: 6-7. } \\
\text { Hukum waris, terdapat di dalam } \\
\text { Q.S. 33: 6; 4: 176; 4: 7-12. } \\
\text { Hukum wasiat, terdapat di dalam } \\
\text { Q.S. 2: 180; 2: } 240 \text { dan 5: } 106 .\end{array}$ \\
\hline & & $\begin{array}{l}\text { Perbandingan } \\
\text { Mazhab }\end{array}$ & 1) & $\begin{array}{l}\text { Setiap umat mempunyai manasik } \\
\text { berbeda-beda, terdapat di dalam } \\
\text { Q.S. } 22: 67 .\end{array}$ \\
\hline
\end{tabular}

Intizar, Volume 24, Nomor 1, 2018 
Toto Suharto

Pemetaan Ayat-Ayat al-Qur'an tentang Rumpun Ilmu Agama dalam Perspektif Paradigma Integrasi-Interkoneksi

\begin{tabular}{|c|c|c|c|c|}
\hline & & & & $\begin{array}{l}\text { Perbedaan cara dan jalan untuk } \\
\text { berlomba dalam kebaikan, terdapat } \\
\text { di dalam Q.S. 5: } 58 \text {. }\end{array}$ \\
\hline & & Jinayah Siyasah & 2) & $\begin{array}{l}\text { Pidana Islam, seperti mencuri, } \\
\text { membunuh, meminum khamr, } \\
\text { berjudi, berzina, menuduh berzina } \\
\text { dan lain-lain, di antaranya terdapat } \\
\text { di dalam Q.S. 5: 38; 4; 92-93; 2: } \\
\text { 178-179; 2: 219; 5: 90-91; 4: 15; 4: } \\
\text { 24; dan 24: 4. } \\
\text { Politik Islam, seperti dasar-dasar } \\
\text { pemerintahan semisal amanah dan } \\
\text { adil, musyawarah, makar, } \\
\text { masyarakat multikultural dan lain- } \\
\text { lain, di antaranya terdapat di dalam } \\
\text { Q.S. 4: 58; 3: 159; 14: 46; 16: } 26 \\
\text { dan 49: } 13 \text {. }\end{array}$ \\
\hline & & Muamalah & 1) & $\begin{array}{l}\text { Transaksi jual beli dan riba, terdapat } \\
\text { di dalam Q.S. 2: } 275 \text {. } \\
\text { Jaminan, pinjaman, hutang-piutang } \\
\text { dan musyarakah, terdapat di dalam } \\
\text { Q.S. 2: } 245 ; 2: 280 \text { dan 2: 282-283. }\end{array}$ \\
\hline \multirow[t]{3}{*}{3} & Ilmu Adab & $\begin{array}{l}\text { Bahasa dan } \\
\text { Sastra Arab }\end{array}$ & 1) & $\begin{array}{l}\text { Al-Qur'an diturunkan dalam Bahasa } \\
\text { Arab, terdapat di dalam Q.S. 12: } 2 \\
\text { dan 43: } 3 \text {. } \\
\text { Sastra al-Qur'an tidak ada yang } \\
\text { menandinginya, terdapat di dalam } \\
\text { Q.S. 2: 23-24; 10: } 38 \text { dan 11: } 13 .\end{array}$ \\
\hline & & $\begin{array}{l}\text { Sejarah dan } \\
\text { Kebudayaan } \\
\text { Islam }\end{array}$ & 2) & $\begin{array}{l}\text { Sejarah kejayaan dan kehancuran } \\
\text { datang silih bergiliran, terdapat } \\
\text { dalam Q.S. 3: } 140 . \\
\text { Hikmah dan pelajaran dari sejarah } \\
\text { masa lalu, terdapat di dalam Q.S. } \\
\text { 20: 99; 18: 13; dan 12: 109-111. }\end{array}$ \\
\hline & & $\begin{array}{l}\text { Perpustakaan } \\
\text { dan Informasi } \\
\text { Islam }\end{array}$ & 1) & $\begin{array}{l}\text { Berlaku adil terhadap pemustaka } \\
\text { yang mencari informasi, tanpa } \\
\text { membeda-bedakan ras, agama, } \\
\text { status sosial, ekonomi, politik dan } \\
\text { jender, kecuali ditentukan oleh }\end{array}$ \\
\hline
\end{tabular}

Intizar, Volume 24, Nomor 1, 2018 
p-ISSN: 1412-1697; e-ISSN: 2477-3816

http://jurnal.radenfatah.ac.id/index.php/intizar

\begin{tabular}{|c|c|c|c|c|}
\hline & & & 4) & $\begin{array}{l}\text { undang-undang yang berlaku. Islam } \\
\text { mengajarkan bahwa keadilan harus } \\
\text { ditegakkan untuk semua manusia, } \\
\text { terdapat di dalam Q.S. 4: } 135 \text { dan 5: } \\
8 . \\
\text { Pustakawan tidak bertanggung } \\
\text { jawab atas informasi yang diperoleh } \\
\text { pemustaka. Hal ini karena setiap } \\
\text { manusia bertangung jawab atas } \\
\text { segala apa yang dikerjakannya, } \\
\text { terdapat di dalam Q.S. 53: 38-40. } \\
\text { Pustakawan melindungi kerahasiaan } \\
\text { informasi yang dicari pemustaka. } \\
\text { Pustakawan adalah seorang yang } \\
\text { amanah, pandai menjaga rahasia } \\
\text { orang lain, terdapat di dalam Q.S. 8: } \\
\text { 27. } \\
\text { Kebenaran informasi perlu diteliti } \\
\text { ulang dan diceksilang, terdapat di } \\
\text { dalam Q.S. 49: 6. }\end{array}$ \\
\hline 4 & Ilmu Dakwah & $\begin{array}{l}\text { Komunikasi dan } \\
\text { Penyiaran Islam }\end{array}$ & 1) & $\begin{array}{l}\text { Proses pewahyuan al-Qur'an } \\
\text { sebagai bentuk komunikasi, terdapat } \\
\text { di dalam Q.S. 42: } 51 \text {. } \\
\text { Tiga kelompok manusia dalam } \\
\text { menyikapi komunikasi al-Qur'an, } \\
\text { terdapat di dalam Q.S. 35: } 32 \text {. } \\
\text { Al-Qur'an adalah bentuk } \\
\text { komunikasi kata-kata yang berat dan } \\
\text { sebagai perkataan terbaik, terdapat } \\
\text { di dalam Q.S. } 73: 5 \text { dan 39: } 23 \text {. }\end{array}$ \\
\hline & & $\begin{array}{l}\text { Bimbingan dan } \\
\text { Konseling Islam }\end{array}$ & 1) & $\begin{array}{l}\text { Jiwa berangsur dewasa sesuai } \\
\text { perkembangan jasmani, terdapat di } \\
\text { dalam Q.S. 22: 5. } \\
\text { Jiwa termasuk urusan Allah, } \\
\text { terdapat di dalam Q.S. 17: } 85 \text {. } \\
\text { Beruntung manusia yang } \\
\text { mensucikan jiwanya, terdapat di } \\
\text { dalam Q.S. 87: }\end{array}$ \\
\hline
\end{tabular}

Intizar, Volume 24, Nomor 1, 2018 
Toto Suharto

Pemetaan Ayat-Ayat al-Qur'an tentang Rumpun Ilmu Agama dalam Perspektif Paradigma Integrasi-Interkoneksi

\begin{tabular}{|c|c|c|c|}
\hline & & & $\begin{array}{l}\text { 4) Mengikuti bimbingan Allah akan } \\
\text { bahagia, terdapat di dalam Q.S. 2: } 5 . \\
\text { 5) Berzikir mengingat Allah membuat } \\
\text { hati menjadi tenang, terdapat di } \\
\text { dalam Q.S. 13: } 28 .\end{array}$ \\
\hline & & $\begin{array}{l}\text { Pengembangan } \\
\text { Masyarakat } \\
\text { Islam }\end{array}$ & 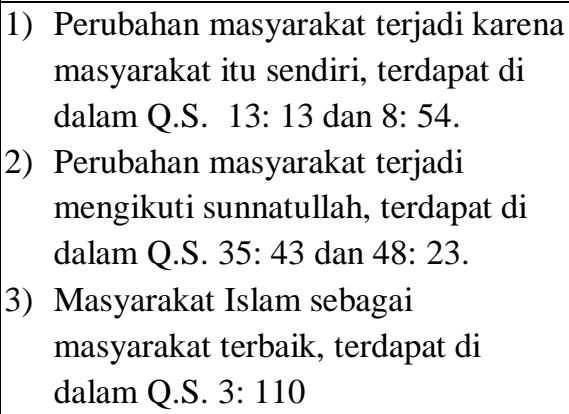 \\
\hline & & $\begin{array}{l}\text { Manajemen } \\
\text { Dakwah }\end{array}$ & $\begin{array}{l}\text { 1) Islam sebagai agama dakwah, } \\
\text { terdapat di dalam Q.S. 3: } 104 . \\
\text { 2) Kesatuan dakwah para nabi, terdapat } \\
\text { di dalam Q.S. 21: } 92 . \\
\text { 3) Misi dakwah adalah menyebarkan } \\
\text { nilai-nilai Islam yang luhur, dari } \\
\text { hidup yang menyesatkan menuju } \\
\text { hidup yang menyelamatkan, } \\
\text { terdapat di dalam Q.S. 10: } 25 . \\
\text { 4) Tugas dakwah Muhammad, terdapat } \\
\text { di dalam Q.S. 7: } 157 . \\
\text { 5) Strategi dakwah, terdapat di dalam } \\
\text { Q.S. 16: } 125 .\end{array}$ \\
\hline 5 & Ilmu Tarbiyah & $\begin{array}{l}\text { Pendidikan } \\
\text { Agama Islam }\end{array}$ & $\begin{array}{l}\text { 1) Tujuan pendidikan Islam adalah } \\
\text { ibadah dalam segala aspek } \\
\text { kehidupan, terdapat dalam 51: } 56 \text {. } \\
\text { 2) Allah adalah pendidik bagi } \\
\text { Muhammad sehingga memiliki } \\
\text { akhlak yang agung, terdapat dalam } \\
\text { Q.S. 68: 4. } \\
\text { 3) Model interaksi guru dan murid, } \\
\text { terdapat di dalam Q.S. 18: 60-82. } \\
\text { 4) Membaca dan menulis sebagai } \\
\text { aktivitas belajar, terdapat dalam } \\
\text { Q.S. 95: 1-5. }\end{array}$ \\
\hline
\end{tabular}

Intizar, Volume 24, Nomor 1, 2018 
p-ISSN: 1412-1697; e-ISSN: 2477-3816

http://jurnal.radenfatah.ac.id/index.php/intizar

\begin{tabular}{|c|c|c|c|c|}
\hline & & & & $\begin{array}{l}\text { Pendidikan harus memperhatikan } \\
\text { fitrah manusia, terdapat di dalam } \\
\text { Q.S. 30: } 30 .\end{array}$ \\
\hline & & $\begin{array}{l}\text { Pendidikan } \\
\text { Bahasa Arab }\end{array}$ & 2) & $\begin{array}{l}\text { Bahasa Arab adalah bahasa al- } \\
\text { Qur'an, terdapat di dalam Q.S. 12: } 2 \\
\text { dan 43: } 3 \text {. } \\
\text { Nabi diutus dengan bahasa kaumnya } \\
\text { di dalam memberikan ajarannya, } \\
\text { terdapat di dalam Q.S. 14: } 4 . \\
\text { Bahasa Arab sebagai pengantar } \\
\text { dalam memberikan peringatan } \\
\text { kepada umatnya, terdapat di dalam } \\
\text { Q.S. 26: 194-195. }\end{array}$ \\
\hline 6 & Ekonomi Islam & $\begin{array}{l}\text { Ekonomi } \\
\text { Syariah }\end{array}$ & 1) & $\begin{array}{l}\text { Kepemilikan sebagai asas } \\
\text { pemanfaatan benda untuk } \\
\text { kepentingan manusia, terdapat di } \\
\text { dalam Q.S. 24: } 33 \text { dan 57: } 7 . \\
\text { Distribusi kekayaan untuk } \\
\text { menjamin pemenuhan kebutuhan } \\
\text { masyarakat, terdapat di dalam Q.S. } \\
\text { 59: } 7 \text {. } \\
\text { Larangan penimbunan harta } \\
\text { kekayaan, terdapat di dalam Q.S. 9: } \\
\text { 34. }\end{array}$ \\
\hline & & $\begin{array}{l}\text { Perbankan } \\
\text { Syariah }\end{array}$ & 1) & $\begin{array}{l}\text { Menghindari sistem bunga yang } \\
\text { berkonotasi riba, terdapat di dalam } \\
\text { Q.S. 4: } 29 \text { dan 3: } 130 . \\
\text { Menggunakan prinsip mudharabah } \\
\text { (bagi hasil dengan tugas masing- } \\
\text { masing), terdapat di dalam Q.S. 73: } \\
20 . \\
\text { Prinsip musyarakah (kerjasama), } \\
\text { terdapat di dalam Q.S. 4: } 12 \text {. }\end{array}$ \\
\hline
\end{tabular}

Demikian, ranah keilmuan PTKI sesungguhnya sudah diberi isyarat dan dan petunjuknya dari ayat-ayat al-Qur'an. Pemberian ayat ini meski terkesan "dipaksakan", tapi ini merupakan bentuk tafsir al-Qur'an terhadap rumpun ilmu agama yang terdapat dalam UU Pendidikan Tinggi. Sekaligus hal ini merupakan 
Toto Suharto

Pemetaan Ayat-Ayat al-Qur'an tentang Rumpun Ilmu Agama dalam Perspektif Paradigma Integrasi-Interkoneksi

langkah ilmiah untuk memantapkan rumpun ilmu agama yang keberadaannya sangat urgen, yaitu sebagai basis konstitusional bagi dunia PTKI di Indonesia.

\section{Perspektif Paradigma Integrasi-Interkoneksi}

\section{Legitimasi al-Qur'an}

Berdasarkan paparan di atas, tampak bahwa wilayah-wilayah pengetahuan yang terdapat dalam rumpun ilmu agama Islam, sebagaimana tertera dalam UU No. 12/2012 tentang Pendidikan Tinggi, kiranya telah mendapat legitimasi al-Qur'an melalui sebaran berbagai ayatnya. Fakultas-fakultas keilmuan, dengan demikian, selain mendapat legitimasi konstitusional, yaitu mendapat basis keilmuannya berdasarkan UU No. 12/2012, juga mendapat justifikasi sebagai sebuah wilayah kajian berdasarkan ayat-ayat al-Qur'an. Legitimasi al-Qur'an ini keberadaannya menjadi penting, karena menjadi dasar pijakan untuk melakukan pengembangan program studi-program studi yang ada di bawahnya.

Sebagai perbandingan, LIPI (Lembaga Ilmu Pengetahuan Indonesia) dalam kaitan itu pernah melakukan pembidangan terhadap wilayah-wilayah yang merupakan bagian dari kajian studi Islam ke dalam delapan pembidangan, yaitu:

a. Sumber ajaran Islam, terdiri atas 1) Ilmu-ilmu Al-Qur'an; 2) Ilmu Tafsir; dan 3) Ilmu Hadis

b. Pemikiran dasar Islam, terdiri atas 1) Ilmu Tauhid/Kalam; 2) Filsafat Islam/Tasawwuf; dan 3) Perbandingan Agama

c. Hukum Islam dan Pranata Sosial, terdiri atas 1) Ushul Fiqh; 2) Fiqh Islam; 3) Pranata Sosial; dan 4) Ilmu Falak dan Hisab

d. Sejarah dan peradaban Islam, terdiri atas:1) Sejarah Islam; dam 2) Peradaban Islam

e. Bahasa dan sastra Islam, terdiri atas: 1) Bahasa Arab; dan 2) Sastra Arab

f. Pendidikan Islam, terdiri atas: 1) Pendidikan dan Pengajaran Islam; dan 2) Ilmu Jiwa Islam

g. Dakwah Islam, terdiri atas: Dakwah Islam

h. Perkembangan modern/pembaharuan dalam Islam, terdiri atas: 1) Bidang sumber ajaran Islam; 2) bidang pemikiran dasar Islam; 3) bidang fiqh dan pranata sosial; 4) bidang sejarah dan peradaban Islam; 5) bidang bahasa dan satra Islam; 6) bidang pendidikan Islam; dan 7) bidang dakwah Islam (Minhaji, 2004, hal. xi-xii).

Dari perbandingan itu tampak bahwa pembidangan ilmu-ilmu keislaman menurut LIPI yang dicanangkan sejak 30 dekade yang lalu, kiranya tidak jauh 
berbeda dengan rumpun ilmu agama Islam yang menjadi konten UU No. 12/2012 sekarang ini. Yang terjadi dalam UU No. 12/2012 menyangkut rumpun ilmu agama Islam adalah perubahan nama atau istilah, yaitu disesuaikan dengan istilah-istilah dalam studi Islam. Sebagai contoh, bidang pemikiran dasar Islam (LIPI) dirubah dalam UU No. 12/2012 menjadi ilmu ushuluddin, bidang hukum Islam dan pranata sosial (LIPI) dirubah dalam menjadi ilmu syariah, atau bidang pendidikan Islam (LIPI) dirubah dalam UU No. 12/2012 menjadi ilmu tarbiyah. Dengan demikian, wilayah kajian rumpun ilmu agama Islam dalam UU No. 12/2012 kiranya hanya merupakan perubahan terminologi bagi nomenklatur keilmuan yang digunakan dalam studi Islam menurut UU No. 12/2012.

Padahal, menurut Akh. Minhaji, studi Islam dengan delapan pembidangan sebagaimana yang ditawarkan LIPI tersebut, dilakukan dalam rangka perubahan dari PTAIN ke IAIN, sehingga didesain masih mengikuti corak dan pola Universitas Al-Azhar, Mesir (Minhaji, 2004, hal. x). Dalam rangka perubahan dari IAIN ke UIN, pembidangan bidang studi-studi Islam oleh LIPI seperti ini sudah tidak memadai lagi. Ia perlu dimodifikasi, bahkan dirombak sama sekali. Hal ini karena sarjana Islam mendatang dituntut bukan lagi mengusung pendapat-pendapat ulama tempo doeloe. Ya, mereka tetap memerlukan ilmu-ilmu klasik, tetapi ilmu-ilmu ini dipahami secara benar untuk kemudian diterjemahkan ke dalam konteks kekinian dengan mengikuti perkembangan ilmu pengetahuan kontemporer. Ditambah lagi, studi Islam konvensional seperti ini sudah tidak lagi sesuai dengan era globalisasi, yang ditandai melalui dunia tanpa batas yang merupakan hasil dari revolusi teknologi informasi (Minhaji, 2004, hal. xiii-xiv).

\section{Rumpun Ilmu Agama Islam menurut "Jaring Laba-Laba”}

Studi Islam sejatinya merupakan hal yang tidak dapat dipisahkan dari pengembangan kualitas intelektual kaum Muslim. Studi Islam dalam maknanya yang paling luas adalah masalah intelektual itu sendiri. Studi Islam yang mengabaikan dimensi intelektual ini akan melahirkan kemandulan dan kebangkrutan intelektualisme di kalangan Muslim (Maarif, 1997, hal. 34). Oleh karena itu, menurut Syafii Maarif, untuk dapat mencapai peningkatan kualitas profesi, seorang Muslim yang melakukan studi Islam harus dapat mendalami bidang spesialisasinya dan disiplin-disiplin terkait yang menjadi keahliannya. Akan tetapi, untuk dapat mengembangkan visi intelektual, seorang ilmuan Muslim harus menerobos batas-batas disiplin yang digelutinya. Dia harus dapat menggumuli agama, filsafat, sejarah, sastra dan wacana-wacana intelektual lainnya. Tanpa 
Toto Suharto

Pemetaan Ayat-Ayat al-Qur'an tentang Rumpun Ilmu Agama dalam Perspektif Paradigma Integrasi-Interkoneksi

bantuan komponen ilmu-ilmu ini, visi intelektual studi Islam akan terpasung oleh spesialisasi bidang yang digelutinya (Maarif, 1997, hal. 37).

Era modernitas telah menyimpan dan menyisakan banyak persoalan yang begitu kompleks. Kompleksitas persoalan-persoalan ini telah sedemikian rupa merembes masuk dan menyentuh seluruh relung-relung kehidupan manusia, termasuk wilayah pemikiran keagamaan (Abdullah, 2000, hal. 20). Dalam konteks ini, kaum agamawan dituntut untuk dapat menyelesaikan persoalan-persoalan itu dan sekaligus meresponinya dengan arif dan bijaksana. Pemikiran keislaman (Islamic thought) oleh karenanya sudah tidak lagi berbicara tentang tipologi pemikiran Islam klasik antara Sunni-Syi'ah atau Salaf-Khalaf. Lebih dari itu, menurut Hassan Hanafi, pemikiran keislaman telah mengalami shifting dari wilayah pemikiran yang dulunya hanya memikirkan persoalan-persoalan "teologi" (ketuhanan) klasik, menuju paradigma pemikiran yang lebih menelaah dan mengkaji secara serius persoalan-persoalan "kemanusiaan" (antropologi) (Abdullah, 1997, hal. 43). Atau dalam bahasa M.M. Sharif (1976, hal. 15), setiap studi Islam harus dikombinasikan dengan kajian humaniora, ilmu-ilmu sosial, dan ilmu kehidupan sehari-hari.

Ketujuh rumpun ilmu agama Islam sebagaimana dalam UU No. 12/2012, dilihat dari terminologi yang digunakan, kiranya masih berada dalam jalur Lingkar Lapis Dua dalam wilayah epistemologi integrasi-interkoneksi model "jaring labalaba". Di dalam epistemologi integrasi-interkoneksi model "jaring laba-laba", Lingkar Lapis Dua adalah mencakup Kalam, Falsafah, Tasawuf, Hadits, Tarikh, Fiqh, Tafsir, dan Lughah. Lingkar Lapis Kedua ini jangkauannya masih berkutat pada $H\{a d\} a>$ rah al-Nas $\{s\}$, yaitu budaya teks yang melahirkan ilmu-ilmu normatif yang tekstual seperti fiqh, kalam, tasawuf, tafsir, hadis, falsafah, dan lughah. Dengan demikian, bidang-bidang pengetahuan dalam rumpun ilmu agama Islam dalam UU No. 12/2012, pada hakikatnya tidak relevan dengan semangat perubahan dari IAIN ke UIN yang menghendaki adanya peningkatan lapisan dalam "Jaring laba-laba" dari Lapis Dua ke Lapis Tiga melalui epistemologi integrasiinterkoneksi.

\section{Rumpun Ilmu Agama: Tidak Implementatif bagi UIN}

Meskipun rumpun ilmu agama dalam UU No. 12/2012 mendapat legitimasi dan justifikasi dari al-Qur'an, namun jika dilihat dari nomenklatur kefakultasan yang ada di UIN, maka dapat dikatakan bahwa wilayah keilmuan dalam rumpun ilmu agama Islam sebagaimana disebutkan dalam UU No. 12/2012 bersifat tidak 
imlpementatif. Lihat misalnya beberapa fakultas yang ada di UIN. UIN Sunan Kalijaga misalnya telah menerapkan nomenklatur fakultasnya sebagai berikut:

a. Fakultas Adab dan Ilmu Budaya, meliputi prodi: 1) Bahasa dan Sastra Arab; 2) Sejarah dan Kebudayaan Islam; 3) Perpustakaan dan Informasi Islam; dan 4) Sastra Inggris

b. Fakultas Dakwah dan Komunikasi, meliputi prodi: 1) Komunikasi dan Penyiaran Islam; 2) Bimbingan dan Konseling Islam; 3) Pengembangan Masyarakat Islam; 4) Manajemen Dakwah; dan 5) Ilmu Kesejahteraan Sosial

c. Fakultas Ilmu Tarbiyah dan Keguruan, meliputi prodi: 1) Pendidikan Agama Islam; 2) Pendidikan Bahasa Arab; 3) Manajemen Pendidikan Islam; 4) Pendidikan Guru Madrasah Ibtidaiyah; dan 5) Pendidikan Guru Raudhatul Athfal

d. Fakultas Syari'ah dan Hukum, meliputi prodi: 1) Al-Ahwal alSyakhsyiyyah; 2) Perbandingan Madzhab dan Hukum; 3) Jinayah Siyasah; 4) Muamalat; 5) Keuangan Islam; dan 6) Ilmu Hukum

e. Fakultas Ushuluddin dan Pemikiran Islam, meliputi prodi: 1) Filsafat Agama; 2) Perbandingan Agama; 3) Ilmu Al-Qur'an dan Tafsir; dan 4) Sosiologi Agama

f. Fakultas Sains dan Teknologi, meliputi prodi: 1) Matematika; 2) Fisika; 3) Kimia; 4) Biologi; 4) Teknik Informatika; 5) Teknik Industri; 6) Pendidikan Matematika; 7) Pendidikan Kimia; 8) Pendidikan Biologi; dan 9) Pendidikan Fisika

g. Fakultas Ilmu Sosial dan Humaniora, meliputi prodi: 1) Psikologi; 2) Sosiologi; dan 3) Ilmu Komunikasi

h. Fakultas Ekonomi dan Bisnis Islam, meliputi prodi: 1) Ekonomi Syariah; dan 2) Perbankan Syariah

Kedelapan fakultas yang ada di UIN Sunan Kalijaga di atas kiranya telah mengikuti pola epistemologi integrasi-interkoneksi model "Jaring laba-laba". Hal ini berbeda dengan wilayah keilmuan dalam rumpun ilmu agama Islam sebagaimana dalam UU No. 12/2012 yang dipandang masih belum mencerminkan epsitemologi ini, yaitu masih menyebutnya dengan ilmu ushuluddin, ilmu syariah, ilmu adab, ilmu dakwah, ilmu tarbiyah dan ilmu ekonomi Islam, tanpa menyertakan "ilmu umum"nya di belakang ilmu-ilmu ini. Dengan demikian, ada semacam missmach antara realitas UIN dengan konten hukum dalam rumpun ilmu agama menurut UU No. 12/2012. Pada konteks inilah UU ini, utamanya terkait dengan 
Toto Suharto

Pemetaan Ayat-Ayat al-Qur'an tentang Rumpun Ilmu Agama dalam Perspektif Paradigma Integrasi-Interkoneksi

keberadaan keilmuan Islam PTAI di Indonesia, dapat dikatakan tidak implementatif. Padahal, menurut UU No. 12/2011 tentang Pembentukan Peraturan PerundangUndangan pasal 5 dinyatakan bahwa salah satu asas pembentukan peraturan perundang-undangan yang baik adalah "dapat dilaksankan". Bagaimana mungkin rumpun ilmu agama Islam dalam UU No. 12/2012 itu dapat dilaksanakan dan bersifat implementatif, apabila materi UU ini secara konseptual belum bersesuaian dengan realitas PTKI, termasuk UIN, yang menghendaki penerapan paradigma integrasi-interkoneksi?

\section{Kesimpulan}

Berdasarkan paparan data pada pembahasan terdahulu, tulisan ini dapat disimpulkan bahwa paradigma keilmuan "integrasi-interkoneksi" merupakan gagasan Prof. M. Amin Abdullah ketika menjadi Rektor UIN Sunan Kalijaga. Jika selama ini terdapat sekat-sekat yang sangat tajam antara "ilmu" dan "agama" di mana keduanya seolah menjadi entitas yang berdiri sendiri dan tidak bisa dipertemukan, maka tawaran paradigma integratif-interkoneksi berupaya mengurangi ketegangan-ketegangan tersebut, tanpa meleburkan satu sama lain, tetapi berusaha mendekatkan dan mengaitkannya sehingga menjadi "bertegus sapa" satu sama lain, yaitu melalu model integrasi keilmuan "Jaring Laba-Laba".

Ketujuh wilayah rumpun ilmu agama Islam, sebagaimana tertera dalam UU No. 12/2012 tentang Pendidikan Tinggi, yaitu ilmu ushuluddin, ilmu syariah, ilmu adab, ilmu dakwah, ilmu tarbiyah, pemikiran Islam, dan ilmu ekonomi Islam, kiranya telah mendapat legitimasi al-Qur'an melalui sebaran berbagai ayatnya dalam bentuk pemetaan, sebagai sebuah wilayah kajian berdasarkan ayat-ayat alQur'an. Ketujuh rumpun ilmu agama Islam ini, dilihat dari terminologi yang digunakan, kiranya masih berada dalam jalur Lingkar Lapis Dua dalam wilayah epistemologi integrasi-interkoneksi model "Jaring Laba-Laba". Di dalam epistemologi integrasi-interkoneksi model “jaring laba-laba” ini, Lingkar Lapis Dua adalah mencakup Kalam, Falsafah, Tasawuf, Hadits, Tarikh, Fiqh, Tafsir, dan Lughah. Dengan demikian, tujuh bidang rumpun ilmu agama Islam dalam UU No. 12/2012 pada hakikatnya tidak relevan dengan semangat perubahan dari IAIN ke UIN yang menghendaki adanya peningkatan lapisan dalam "Jaring laba-laba" dari Lapis Dua ke Lapis Tiga melalui paradigma integrasi-interkoneksi. Pada sisi yang lain, jika dilihat dari nomenklatur kefakultasan yang ada di UIN, maka dapat dikatakan bahwa tujuh bidang keilmuan rumpun ilmu agama Islam itu tidaklah 
implementatif, karena ada semacam missmach antara realitas UIN dengan konten hukum dalam rumpun ilmu agama menurut UU No. 12/2012.

Dengan temuan-temuan di atas, tulisan ini memberikan rekomendasi bahwa kajian ini baru sebatas mengkaji pemetaan ayat-ayat al-Quran tentang rumpun ilmu agama sebagaimana tertera dalam UU No. 12/2012. Kajian semacam ini mengesankan kentalnya normativitas Islam. Untuk itu, tulisan ini memerlukan kajian lanjutan yang lebih menekankan historisitas Islam, misalnya melihat ayatayat al-Quran itu berdasarkan sistem kefakultasan di UIN-UIN, yang sudah membuka fakultas-fakultas umum, sehingga kajian dengan tema ini semakin bersifat holistik dan komprehensif. Selain itu, pemerintah dan DPR dapat melakukan tinjauan ulang atas materi hukum mengenai rumpun ilmu agama, khususnya Islam, dalam UU No. 12/2012, karena hanya membagi kajian keislaman dalam enam bidang wilayah keilmuan, padahal realitas di UIN-UIN yang di Indonesia menunjukkan perkembangan yang lebih positif, yaitu dengan membuka lebih dari enam bidang kajian, seperti fakultas kedokteran, fakultas sosial humaniora serta dan sains dan teknologi. 
Toto Suharto

Pemetaan Ayat-Ayat al-Qur'an tentang Rumpun Ilmu Agama dalam Perspektif Paradigma Integrasi-Interkoneksi

\section{Daftar Pustaka}

Abdullah, M. A. (1997). Falsafah Kalam di Era Postmodernisme. Yogyakarta: Pustaka Pelajar.

Abdullah, M. A. (2000). Dinamika Islam Kultural: Pemetaan Atas Wacana Keislaman Kontemporer. Bandung: Mizan.

Abdullah, M. A. (2006). Islamic Studeis di Perguruan Tinggi: Pendekatan Integratif-Interkonektif. Yogyakarta: Pustaka Pelajar.

Baiquni, A. (1997). Al-Qur'an dan Ilmu Pengetahuan Kealaman. Yogyakarta: Dana Bakhti Prima Yasa.

Hasan, M. T. (2005). Prospek Islam dalam Menghadapi Tantangan Zaman. Jakarta: Lantabora Press.

Kalijaga, U. S. (2013, Desember 12). Visi \& dan Misi. Retrieved from UIN Sunan Kalijaga: http://uin-suka.ac.id/index.php/page/universitas/2

Kartanegara, M. (2006). Reaktualisasi Tradisi Ilmiah Islam. Jakarta: Baitul Ihsan.

Maarif, A. S. (1997). Islam: Kekuatan Doktrin dan Kegamangan Umat. Yogyakarta : Pustaka Pelajar.

Minhaji, A. (2004). Transformasi IAIN Menuju UIN: Sebuah Pengantar. In M. A. Abdullah, Integrasi Sains-Islam: Mempertemukan Epistemologi Islam dan Sains. Yogyakarta: Pilar Religia-SUKA Press.

Sharif, M. M. (1976). Islamic and Educational Studies. Lahore: Muhammad Ashraf Darr.

Suharto, T. (2014). Studi Islam di Era Multikultural: Respons UIN terhadap Kebijakan Rumpun Ilmu Agama. 14th Annual International Conference on Islamic Studies (AICIS). Balikpapan: Diktis Kementerian Agama RI.

Suprayogo, I. (2013, Desember 10). Paradigma Wider-Mandate dalam Pengembangan PTAIN. Retrieved from UIN Malang: http://uinmalang.ac.id/index.php?option=com_content $\&$ view $=$ article $\&$ id $=3406 \% 3$ Aparadigma-wider-mandate-dalam-pengembanganptain\&catid $=25 \% 3$ Aartikel-rektor\&Itemid $=4$ 